\title{
Faktor Dalam Negeri dan Luar Negeri dalam Memberikan Stimulasi Pergerakan Indeks Harga Saham LQ45
}

\author{
Oleh: \\ Tiar Lina Situngkir \\ Program Studi S1-Manajemen Fakultas Ekonomi Universitas Singaperbangsa Karawang \\ email: tiarlina.situngkir@fe.unsika.ac.id
}

\begin{abstract}
ABSTRAK
Penelitian ini bertujuan untuk menganalisa faktor dalam negeri diproksi dengan suku bunga, nilai tukar dan inflasi, serta faktor luar negri yang diproksi dengan indeks saham STI untuk negara Singapura dan Indeks saham KLSE untuk negara Malaysia. Data yang digunakan pada penelitian ini adalah data sekunder, data bulanan pada periode januari 2013 sampai dengan Desember 2019 dari situs www.investing.com. Penelitian ini menggunakan pendekatan deskripstif kuantitatif, dengan teknik analisa menggunakan metode Eror Koreksi Model.Hasil penelitian menginformasikan bahwa pada jangka pendek hanya nilai tukar rupiah terhadap dolar yang memberikan pengaruh gejolak pada indeks harga saham LQ45. Sedangkan pada kurun waktu jangka panjang semua faktor dalam negri yang diwakili suku bunga, nilai tukar, dan inflasi serta faktor luar negri yang diwakili STI dan KLSE memberikan dampak terhadap goncangan pada indeks harga saham LQ45.
\end{abstract}

Kata kunci: Makroekonomi, STI,KLSE, LQ45

\section{ABSTRACT}

This study aims to analyze intern factors proxied by interest rates, exchange rates and inflation, as well as foreign factors proxied by the STI stock index for Singapore and the KLSE stock index for Malaysia. The data used in this study are secondary data, monthly data for the period January 2013 to December 2019 from the site www.investing.com. This study uses a quantitative descriptive approach, with the analysis technique using the Model Correction Error method. The results of this study inform that in the short term only the exchange rate of the rupiah against the dollar has an effect of volatility on the LQ45 stock price index. Meanwhile, in the long term all domestic factors represented by interest rates, exchange rates, inflation and foreign factors represented by STI and KLSE have an impact on shocks on the LQ45 stock price index.

Keywords: Interest Rate, Exchange Rate, STI, KLSE, LQ45

\section{PENDAHULUAN}

Pergerakan indeks harga saham merupakan indikasi situasi perekonomian suatu negara. Pergerakan yang positif atau tren menanjak memberikan gambaran respon baik pasar pada modal. Sedangkan menurunnya trend indeks harga saham memberikan indikasi ekonomi yang lesu.
Peristiwa ini menjadi pemicu untuk dilakukan penelitan faktor-faktor yang memberikan pengaruh pada pergerakan indeks harga saham pada suatu negara.

Perekonomian suatu negara berjalan dengan beragam faktor yang mempengaruhi. Faktor makroekonomi memiliki andil dalam mempengaruhi 
guncangan pada harga indeks saham pada pasar modal dalam negeri, selain itu faktor dari luar negri juga bisa memberikan andil pada pergerakan indeks harga saham di pasar modal Indonesia. (Jin, 2016).

Hal ini menjadi menarik untuk diteliti bagaimana faktor dalam negri dan faktor luar negeri mempengaruhi indeks saham di Indonesia. Faktor dalam negeri yang diobservasi pada penelitian ini adalah suku bunga, nilai tukar, dan inflasi. Untuk indeks harga saham yang diobservasi adalah indeks saham LQ45. Faktor dari luar negri yang diteliti adalah indeks saham negara tetangga, yang digunakan sebagai proksi pada penelitian adalah indeks harga saham singpura (STI) dan indeks harga saham malaysia (KLSE). (Shalini, Velappan dan Prasanna, 2016).

Beberapa penelitian sebelumnya telah memberikan informasi hasil yang bervariasi. Variabel-variabel faktor makroekonomi terbukti memberi andil dalam mempengaruhi goncangan dari indeks harga saham LQ45. (Prasetiono, 2010) melakukan penelitian dengan menggunakan empat variabel fundamental yang terdiri dari pertumbukan ekonomi, Suku Bunga Bank Indonesia, dan nilai tukar mata uang serta harga minyak dunia memberikan dampak pada goncangan indeks harga saham LQ45. Riset yang berbeda juga dilaksanakan oleh (Ira Roshita Dewi \& Sri Artini, 2016) meneliti faktot fundamental perusahaan yaitu pendapatan per saham, imbal hasil atas ekuitas, dan rasio hutang pada ekuitas serta faktor makroekonomi yang diwakili oleh inflasi dan suku bunga SBI terhadap harga saham pada perusahaan Indeks LQ-45 di Bursa Efek Indonesia (BEI) periode 2011-2014. Kemudian penelitian lainnya oleh (Aurora \& Riyadi, 2013) memilih beberapa variabel faktor makroekonomi yaitu inflasi, suku bunga Sertifikat Bank Indonesia, dan nilai tukar mata uang rupiah terhadap pergerakan indeks saha LQ-45 pada bursa efek Indonesia periode 2007 hingga 2011.

Menilik dari beberapa penelitian yang telah terlebih dahulu dilakukan tersebut maka penelitian ini akan menjadikan faktor internal dalam negeri sebagai variabel bebas $(\mathrm{X})$ yang terdiri dari dari faktor makroekonomi yang diwakili oleh suku bunga, dan nilai tukar rupiah serta dua indeks harga saham negara tetangga yang terdiri dari Strait Times Indeks, mewakili harga saham negara Singapura dan KLSE merepresentasikan harga saham Malaysia sedangkan sebagai variabel terikat (Y) adalah indeks harga saham LQ45. Sehingga hipotesa yang akan diuji adalah apakah ada pengaruh signifikan variabel $\mathrm{X}$ yang terdiri dari suku bunga, inflasi dan nilai tukar rupiah terhadap dolar, serta indeks STI juga indeks KLSE terhadap variabel Y yaitu indeks LQ45. Dan yang menjadi menarik dari beberapa penelitian sebelumnya lebih 
banyak meneliti pada indeks harga saham gabungan Indonesia, masih belum banyak yang meneliti indeks saham tetangga yang mempengaruhi indeks harga saham LQ45. Ini menjadi salah satu hal yang bisa dipertimbangan untuk dapat membantu membentuk sistem informasi dini mengantisipasi gejolak pada faktor dalam dan luar negri terhadap indeks harga saham, bagi pengguna informasi.(Firdausi et al., 2016)

Dengan demikian maka tujuan yang akan dicapai dalam penelitian ini adalah bisa mengetahui bagaimana pengaruh dari variabel-variabel $\mathrm{X}$ yang akan diteliti yaitu suku bunga, inflasi dan nilai tukar rupiah serta indeks harga saham STI juga KLSE dalam memberikan dampak goncangan pada variabel Y yaitu indeks harga saham LQ45. Selain itu juga bisa menjadi masukan sebagai antisipasi dini bagi para investor untuk menentukan langkah investasi dimasa depan dengan melihat perubahan pada faktor internal dan eksternal.

\section{TINJAUAN PUSTAKA}

Penelitian ini akan melihat bagaimana kontribusi variabel-variabel faktor makroekonomi yang terdiri dari suku bunga, nilai tukar dan inflasi, serta indeks harga saham tetangga bisa memberi dampak guncangan terhadap indeks harga saham LQ45 pada pasar modal Indonesia. Berdasarkan payung hukum UU R.I No. 8
Tahun 1995, Pasar Modal adalah kegiatan yang berkaitan dengan penawaran umum dan perdagangan surat berharga, perusahaan terbuka yang berkaitan dengan surat berharga yang diterbitkannya, serta lembaga dan profesi yang berkaitan dengan surat berharga.

Penelitian ini akan melihat bagaimana kontribusi variabel-variabel faktor makroekonomi yang terdiri dari suku bunga, nilai tukar dan inflasi, serta indeks harga saham tetangga bisa memberi dampak guncangan terhadap indeks harga saham LQ45 pada pasar modal Indonesia. Berdasarkan payung hukum UU R.I No. 8 Tahun 1995, Pasar Modal adalah kegiatan yang berkaitan dengan penawaran umum dan perdagangan surat berharga, perusahaan terbuka yang berkaitan dengan surat berharga yang diterbitkannya, serta lembaga dan profesi yang berkaitan dengan surat berharga.

Perusahaan yang terdaftar pada indeks LQ45 merupakan perusahaan yang memiliki kinerja yang baik dengan indikasi tingkat transaksi kategori tinggi dan likuid. Komunitas ini terdiri dari 45 saham terbaik dan kapitalisasi pasar yang besar serta telah memenuhi persyaratan berdasarkan beberapa ketentuan pengujian (Tandelilin, 2010). Suku bunga merupakan salah satu faktor makro ekonomi yang memberikan informasi tingkat bunga yang berlaku pada suatu saat peristiwa. Informasi suku bunga 
ditentukan berdasarkan informasi yang diumumkan oleh Bank sentral Indonesia, dalam hal ini Bank Indonesia, maka segala transaksi pada perusahaan dan lembaga keuangan akan merujuk ke suku bunga yang diterbitkan bank Indonesia sebagai acuannya. (Arnold, 2019)

Nilai tukar mata uang adalah salah satu faktor yang dibutuhkan kegiatan transaksi ekonomi. Transaksi yang terjadi memicu pergerakan pada nilai tukar mata uang menjadi lebih tinggi atau lebih rendah pada saat tertentu. Goncangan yang berubah-ubah bisa mempengaruhi nilai dari tiap transaksi yang dilakukan. Inflasi merupakan faktor yang terjadi disebabkan karena perubahan permintaan dan harga barang yang terjadi di pasar. Kecepatan perubahan permintaan atas barang mempengaruhi harga barang tersebut sehingga mengakibatkan laju inflasi juga berubah. Dengan perubahan laju inflasi memberikan pengaruh pada harga barang menjadi lebih tinggi. (Arnold, 2019)

Faktor luar negri yang digunakan sebagai proksi dalam penelitian kali ini adalah indeks negara tetangga yang berdekatan secara lokasi dengan Indonesia yaitu negara Singapura yang diwakili oleh indeks STI dan indeks negara Malaysia yaitu KLSE. Dengan kondisi yang berdekatan ada kemungkinan memberikan pengaruh antar indeks negara yang saling bertetangga. (Tiar Lina Situngkir, 2019)

\section{METODE PENELITIAN}

Penelitian menggunakan data sekunder dari harga saham yang tersedia di situs www.investing.com. Data yang digunakan adalah data bulanan dari periode januari 2013 sampai dengan Desember 2019. Penelitian ini menggunakan pendekatan deskriptif dan kuantitatif dengan metode error correction. Dengan menggunakan metode ini, riset akan diteliti dampaknya dalam kurun waktu pendek dan kurun waktu panjang.

Penelitian ini melakukan pemaparan serta melakukan analisa pengaruh kurun waktu pendek dan jangka panjang dari suku bunga, inflasi dan nilai tukar rupiah serta indeks harga saham STI juga KLSE dalam memberikan dampak goncangan pada indeks harga saham LQ45. Metode kuantitatif Error Correction Model (ECM) pada penelitian ini, mengasumsikan adanya keseimbangan (equilibrium) dalam jangka panjang antara variabel-variabel ekonomi. Dalam kurun waktu pendek bila pada suatu periode belum mencapai ketidakseimbangan ( disequilibrium, maka pada kurun waktu berikutnya dalam rentang waktu tertentu mengalami proses koreksi penyesuaian sehingga mampu mencapai posisi keseimbangan (N.D nachrowi, 2006).

Analisa data dalam penelitian ini meliputi: pertama adalah menguji stasioneritas data. Uji Akar-akar unit bisa dikatakan sebagai uji stasioner karena pada 
prinsipnya, uji ini dilakukan untuk mengamati apakah koefisien tertentu dari model otoregresif yang ditaksir mempunyai nilai yang sama atau tidak. Hal ini dilakukan karena sebelum melakukan uji kointegrasi, perilaku data time series harus diamati dengan uji akar-akar unit. Sebab, perilaku data runtun waktu (time series) dapat dipandang sebagai uji prasyarat dalam penggunaan pendekatan kointegrasi.

Selanjutnya dilaksanakan uji derajat integrasi. Uji ini digunakan apabila pada uji akar-akar tidak stasioner, atau dengan kata lain untuk mengetahui pada derajat berapa data yang diamati akan stasioner. Model awal yang digunakan dalam penelitian ini adalah sebagai berikut:

$\mathrm{Y}=\mathrm{a}+\mathrm{b} 1 \mathrm{INF} 1+\mathrm{b} 2$ KURS $2+\mathrm{e}$

Setelah menentukan model awal analisis, berikutnya adalah menemukan nilai residual yang dari model yang dinamakan dengan Error Correction Term (ECT). Uji berikutnya adalah kointegrasi yang merupakan lanjutan dari uji akar-akar unit dan uji derajat integrasi. Uji kointegrasi bertujuan untuk menguji apakah residual regresi (ECT) yang dihasilkan stasioner atau tidak (N.D nachrowi, 2006). Dalam melakukan uji kointegrasi harus diketahui terlebih dahulu apakah data-data yang digunakan sudah stasioner serta mempunyai derajat integrasi yang sama. Maka dapat dituliskan persamaan ECM sesuai dengan hipotesis, yaitu:

DYt $=a+b 1$ INF $1 t+b 2$ KURS2 $t+b 3$ ECTt $1 \ldots \ldots \ldots . . .(2)$

\section{HASIL DAN PEMBAHASAN}

Dari hasil olah data yang dilakukan maka ditemukan bahwa semua variabel stasioner pada tingkat level pertama dengan nilai masing-masing adalah 0.00. Sesuai dengan aturan dari teknik analisa yang digunakan ECM. Berarti variabel suku bunga, nilai tukar, inflasi, indeks harga saham tertangga yang terdiri dari indeks STI dan indeks KLSE serta indeks harga saham LQ45 memenuhi persyaratan dalam analisa dengan metode ini.

\begin{tabular}{|c|c|}
\hline Keterangan & $\begin{array}{l}\text { Tingkat } \\
\text { Stasioner }\end{array}$ \\
\hline Suku Bunga & $\begin{array}{l}\text { Tingkat } \\
\text { pertama }\end{array}$ \\
\hline $\begin{array}{l}\text { Nilai Tukar } \\
\text { Inflasi }\end{array}$ & $\begin{array}{l}\text { Tingkat } \\
\text { pertama }\end{array}$ \\
\hline & $\begin{array}{l}\text { Tingkat } \\
\text { pertama }\end{array}$ \\
\hline STI & $\begin{array}{l}\text { Tingkat } \\
\text { pertama }\end{array}$ \\
\hline KLSE & $\begin{array}{l}\text { Tingkat } \\
\text { pertama }\end{array}$ \\
\hline
\end{tabular}

Maka tahap selanjutnya bisa dilakukan yaitu uji kointegrasi. Pada tahapan ini data yang ditampilkan adalah nilai residual adalah 0.00 hal ini bermakna syarat bahwa masing-masing variabel yang 
terlibat pada penelitian ini memiliki kointegrasi.

Tabel 2 : Nilai Residul Variabel

\begin{tabular}{lc}
\hline Keterangan & Nilai \\
\hline Residual & 0.00 \\
& \\
\hline \multicolumn{2}{l}{ Sumber data $:$ Diolah } \\
\hline
\end{tabular}

Dari semua tahapan sebelumnya memberikan informasi bahwa persyaratan yang dibutuhkan dalam teknik analisa ini sudah terpenuhi maka berikutnya proses menunjukkan persamaan pada kurun waktu pendek memberikan informasi bahwa hanya nilai tukar yang signifikan berpengaruh pada periode ini. Sedangkan variabel lainnya tidak signifikan mempengaruhi pda kurun waktu pendek karena nilainya lebih dari $5 \%$.

Tabel 3 : Persamaan Jangka Pendek

\begin{tabular}{ll}
\hline Keterangan & $\begin{array}{l}\text { Tingkat } \\
\text { Stasioner }\end{array}$ \\
\hline Suku Bunga & 0.4423 \\
Nilai Tukar & 0.0006 \\
Inflasi & 0.4129 \\
STI & 0.2359 \\
KLSE & 0.1459 \\
\hline \multicolumn{2}{l}{ Sumber data: Diolah } \\
\hline
\end{tabular}

Kemudian pada kurun waktu jangka panjang, data memberikan informasi semua variabel signifikan mempengaruhi pergerakan indeks harga saham LQ45. Hal ini ditunjukkan dengan hasil nilai proses yang lebih dari $5 \%$.
Tabel 4 : Persamaan Jangka Panjang

\begin{tabular}{ll}
\hline Keterangan & $\begin{array}{l}\text { Tingkat } \\
\text { Stasioner }\end{array}$ \\
\hline Suku Bunga & 0.0000 \\
Nilai Tukar & 0.0000 \\
Inflasi & 0.0000 \\
STI & 0.0000 \\
KLSE & 0.0000 \\
\hline \multicolumn{2}{l}{ Sumber data : Diolah } \\
\hline
\end{tabular}

Hasil proses data pada penelitian ini, menjelaskan bahwa pada kurun waktu jangka pendek, variabel nilai tukar memberi kontribusi dalam gerak goncangan pada indeks harga saham LQ45. Sejalan dengan hasil penelitian dari (Tiar Lina Situngkir, 2020), (Firdausi et al., 2016).

Kondisi ini perlu dicermati oleh para pelaku pasar dan pemerintah untuk lebih berhati menjaga stabilitas nilai tukar pada kurun waktu jangka pendek karena variabel ini sangat signifikan dalam mempengaruhi pergeraka indeks harga saham LQ45. Sehingga akan memberikan terjadinya peningkatan transaksi saham pada kelompok ini.

Pada kurun waktu jangka panjang, hasil yang ada memberikan bukti bahwa semua variabel independen makroekonomi yang terdiri dari suku bunga, nilai tukar, inflasi berpengaruh signifikan, demikian juga variabel eksternal yang terdiri dari indeks harga saham negara tetangga yang diwakili STI dari negara Singapura dan 
KLSE untuk Malaysia, memberikan kontribusi terhadap goncangan indeks saham LQ45. Hal ini seiring dengan hasil penelitian (Tiar Lina Situngkir, 2019), (Firdausi et al., 2016), (Salim, 2017), (Prasetiono, 2010) menemukan bahwa faktor makroekonomi dan indeks harga saham negara tetangga berpengaruh memberikan dampak gejolak pada indeks saham di pasar modal.

Maka pada penelitian ini menegaskan bahwa variabel $\mathrm{X}$ sangat memberikan kontribusi pegaruh pada pergerakan variabel Y pada periode waktu jangka panjang.

$$
\text { Investasi yang dilakukan }
$$

berorientasi pada kurun waktu jangka panjang. Sehingga kondisi pada masa ini harus lebih diperhatikan. Pembuktian pada penelitian ini bisa menjadi masukan bagi pembuat kebijakan untuk lebih memperhatikan langkah yang terbaik dalam membentuk kebijakan ekonomi yang mampu mengadaptasi setiap peristiwa ekonomi yang terdampak pada perubahan faktor-faktor makroekonomi terutama suku bunga, nilai tukar, inflasi dan STI serta KLSE dalam hal ini indeks saham LQ45.

Kenyataan indeks harga STI dan KLSE memberikan gerakan gejolak pada indeks harga saham LQ45 memberikan ada indikasi kegiatan transaksi ekonomi yang cukup intens diantara kedua masing-masing negara.
Perusahaan yang terdaftar pada indeks LQ45 adalah perusahaan yang memiliki kinerja yang baik. Dengan demikian goncangan yang diharapkan terjadi pada indeks ini adalah yang mampu memberikan imbal hasil yang menguntungkan pada perusahaanperusahaan tersebut. Goncangan yang justru memporak-porandakan perusahaan, bukanlah hal yang diharapkan terjadi pada komunitas perusahaan yang bernaung pada indeks saham terfavorit para investor, terutama para investor retail.

Penelitian ini bisa memberikan bukti sebagai informasi bagi para investor untuk mengambil sikap penyesuaian atas transaksi investasi yang dilakukan jika pergerakan faktor-faktor makroekonomi mengalami perubahan secara terus menerus dalam kurun waktu jangka panjang. Namun tidak perlu mengambil langkah secara berlebihan apabila perubahan terjadi pada masa yang singkat.

\section{KESIMPULAN}

Dari hasil penelitian ini dapat disimpulkan bahwa faktor dalam negeri yang diproksi dengan suku bunga, kurs, dan inflasi serta faktor luar negeri yang diproksi dengan STI dan KLSE memberikan temuan yaitu pada kurun waktu jangka pendek hanya nilai tukar atau kurs yang memberikan pengaruh signifikan pada gejolak pada indeks harga LQ45. Sedangkan 
pada kurun waktu jangka panjang, semua faktor dalam negeri dan luar negeri memberikan kontribusi secara signifikan pada perubahan goncangan pada indeks harga saham LQ45.

Saling mempengaruhi antar negara tetangga juga ada baiknya membuat negara kita mampu terus meningkatkan kualitas domestiknya agar mampu bersaing dalam perekonomian untuk menarik investor asing berinvestasi di negara kita dimasa yang akan datang. (Firdausi et al., 2016)

Peristiwa ini membuktikan bahwa perlu dilakukan suatu sistem yang mumpuni untuk menjadi peringatan awal yang mampu menampilkan indikasi perubahan yang terjadi sehingga memberikan informasi bagi pembuat kebijakan dalam menentukan arah kebijakan yang dibuat di masa tertentu. Dan ini juga bisa membantu para investor menentukan kegiatan transaksi yang tepat terhadap investasi saham yang mereka lakukan pada saham-saham yang berada pada pasar modal. (Firdausi et al., 2016)

\section{DAFTAR PUSTAKA}

Arnold, R. A. (2019). ECONOMICS (13th ed.). Learning, Cengage Reserved, All Rights.

Aurora, T., \& Riyadi, dan A. (2013). Pengaruh Inflasi, Suku Bunga, dan Kurs Terhadap Indeks LQ-45 di Bursa Efek Indonesia Periode Tahun 2007-2011. Jurnal Dinamika
Manajemen, 1(3), 184.

Firdausi, A. N., Fahmi, I., \& Saptono, I. T. (2016). Pengaruh Indeks Harga Saham Regional ASEAN dan Variabel Makroekonomi terhadap Indeks Harga Saham Syariah Indonesia (ISSI). Al-Muzara'ah, 4(2), 76-96. https://doi.org/10.29244/jam.4.2.7696

Ira Roshita Dewi, A., \& Sri Artini, L. (2016). Pengaruh Suku Bunga Sbi, Inflasi, Dan Fundamenal Perusahaan Terhadap Harga Saham Indeks Lq45 Di Bei. E-Jurnal Manajemen Universitas Udayana, 5(4), 253314. Jin, X. dan A. X. (2016). "Global Financial Crisis And Emerging Stock Market Contagion: A Volatility Impulse Response Function Approach.” Research in International Business and Finance., 179-195.

Prasetiono, D. W. (2010). Analisis Pengaruh Faktor Fundamental Ekonomi. 4(1), 11-25.

Salim, J. F. (2017). Pengaruh Faktor Dalam Dan Luar Negeri Terhadap Indeks Harga Saham Gabungan (Ihsg) Di Indonesia. Jurnal Ekonomi Dan Kebijakan Publik Indonesia, 4(1), $35-48$.

Shalini, Velappan dan Prasanna, K. (2016). "Impact Of The Financial Crisis On Indian Commodity Markets: 
JAFTA - Vol 2 Nomor 1, Oktober (2020)

Structural Breaks And Volatility

Dynamics”. Energy Economics., 40

57.

Tandelilin, E. (2010). Analisis Investasi dan Manajemen Portofolio. (Edisi Ketu). Kanisius.

Tiar Lina Situngkir. (2019). Pengaruh Dow Jones Indeks, Strait Time, dan Hang Sheng Terhadap Indeks Harga Saham Gabungan dengan Pendekatan Eror Correction Model. Jurnal Mandiri : Ilmu Pengetahuan, Seni, Dan Teknologi, 3(2), 307-313.

Tiar Lina Situngkir1, R. L. B., \& Fakultas. (2020). Sentralisasi Volume 9 No ( 1 ) : 36-44 2020 Sentralisasi Volume 9 No ( 1 ) : 36-44 2020. Sentralisasi, 9(1), 36-44. 
JAFTA - Vol 2 Nomor 1, Oktober (2020) 